\title{
STUDIES ON PGSR AUDIOMETRY
}

Part I. Results of PGSR audiometry applied on persons with different hearing acuity

By

M. KANADANI

\section{From the Department of Oto-Rhino-Laryngology Okayama University Medical School \\ (Director: Prof. S. Takahara)}

The author devised an apparatus that can give a current amplitude necessary and sufficiently stable for recording the psycho-galvanic skin response. Namely, with a Wheatstone birdge as the circuit for measuring the psycho-galvanic skin response current is passed through a DC-AC conv. erter, the current chopper, and through the amplifier with the common time constant and then it is passed through a synchronizing rectifier and finally into the ink-writing oscillograph.

Using this apparatus, the author took the recors of the entire course of examinations by PGSR audiometry on persons with different hearing acuity at each frequency of 500,1000, 2000 and 4000 cps. Following up this, subjective hearing tests were conducted, and the results of these two methods were compared. Those showing the difference with $5 \mathrm{db}$ between the two methods were seen in 65 to 85 per cent of the cases, indicating a sufficient reliability in practical use of the test as the objective hearing test.

Those conditioned less than 50 times amounted to $13(65 \%)$ out of 20 children with normal hearing of both ears, $10(55 \%)$ out of 18 children with one normal ear and a moderate hearing loss in the other side, $8(67 \%)$ out of 12 children with moderate hearing loss of both ears, and 27 (90\%) out of 30 children with severe hearing loss.

Compared with the averege age of 14 years in the first three groups, (the average of successful cases was 13 years while that of failure was 15 years), the rate of success in the latter severe hearing loss with the average of 8 years (average age for successful ones and failures was 8 years) was higher. Amoug those above the first grade, younger ones were more apt to be conditioned.

Children with severe hearing loss have been found different from other children tested, being their attention more readily called to sounds and more easily conditioned than those in other groups.

\section{PGSR 法に関する 研 究}

\section{第 1 篇 各種聴力者の PGSR 法による検査成績に就いて} 岡山大学医学部耳算咽喉科教空（主任：高原滋夫教授）

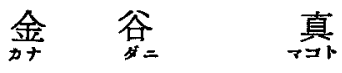

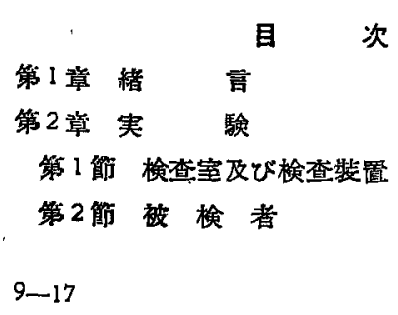

\section{第3 盆 実験方法} 第3章 実験成組

第1節 正常耳の PGSR 法並びに゙自賞法による㭘 查成綪

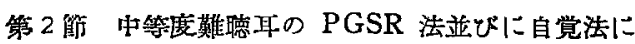




\section{よる検沓成紹}

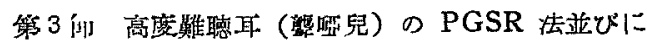
目党去による検梪成絬

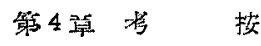

第 5 学 絃语

\section{第1章 緒䨐}

現在行なわ机ている普通の㙂つ検查佉の大きな欠占

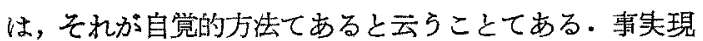

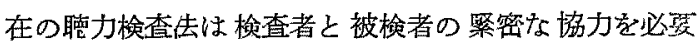
とし，被検者は自分自身の返答によつて，自分の塄覚閶 值を自ら示すものである・この自覚的方位てあるという 事定から，被検者が機能的な難聴の場合てあるとか，幼 小罗の場合と加には普通の聴力検查法は全く失敗に終

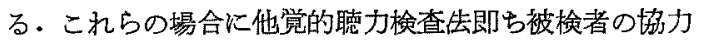
を必要とせず，そしてあるいは被検者の意志に反してさ 它も行い得る聴力検查佉が望をれる。このような目的の ため現在迄に数多くの方法が研究された。睬波の利用，

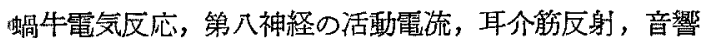

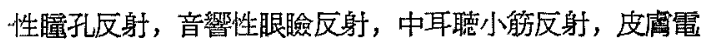
流反射等数多くの方法が考光られたが，いすれれる我々の 其待を裏切り，ある物は满足な成續が得られず，ある物 は実験的には成功しても実際的てはなかつた。他覚的聴 力榆查法を雌立しようとして皮成電流反射を利用しよう といら考文は, 1947 年既に Michels 及ひ Raadt の脳雲にあつた・しかしこの两者の方法は不完全なるの てあつた・彼等は脳波描写器の上に皮膚電流反射を直接 記入乙条件付けの方法を用いなかつた・即ち音の直接反 射を用いたのて，この反射恃急速に減弱し，特殊の場合 の他さして有効てなかつた。

1947 年 Bordley 及び Hardy は Pavlov の条件反 射及び皮虜雪流反射を利用した他覚的聴力検查法であ る Psycho Galvanic Skin Responce Audiometry 即] ち PGSR を発表した。この方法は現在迄の各種他賞的 検查法の中で最も合理的てあり，最も実用的であると考 劣られる力法てあるが，複䧱な装置を必要とし，本法の 適応範囲，信頼度に種々異論もあるので, 私はこの検查 法に検訂を加光，装置の改良簡易化を図り，検查技術， 検查精度の向上を図るため，聴力正常者，各種中等度難

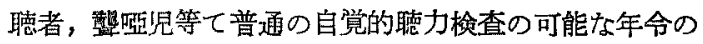
者につき, 私の考按試作した装置を使用して得たPGSR 失による成績之普通の自賞的聴力検查法による成樍とを 比較し，その信頼度及ひ検查の失敗原因について子积討 を試みた。

\section{第 2 章 実験}

第 1 節 検査室及び検查溒置

検查室は岡大医学部耳鼻咽喉利教室の一辺 $3 \mathrm{~m}$ の正方 形て電気的にも完全に Shield さ初た防音室である・陆 器類は本実験の性質上第 1 图の如くすべて䇟室に置き， その部屋と防音室の䎋壁にはマジックミラーの窓が設け られ，検者はその空を通して防音室内の被検者を観察し ながら檢查を行なえるよらになつている。

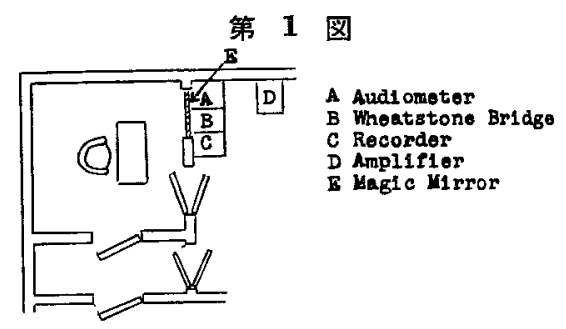

第 2 区（A）

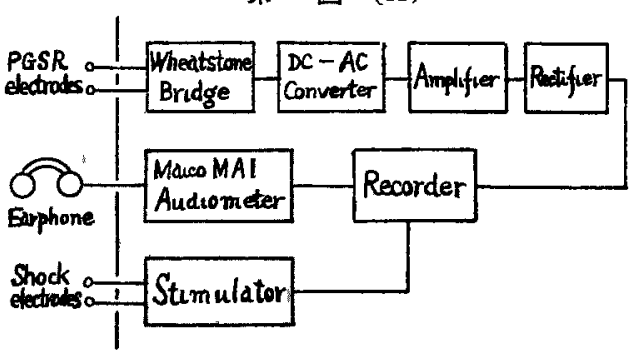

(B)

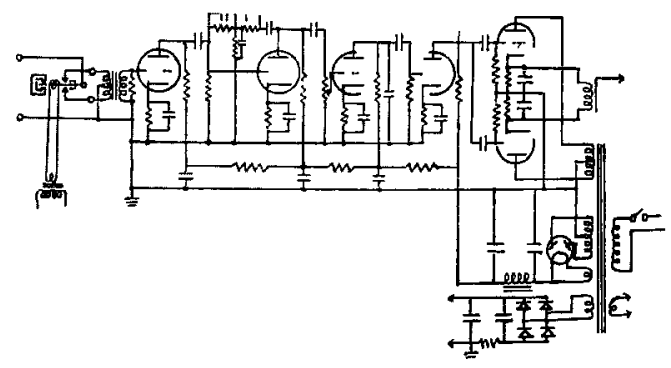

(C)

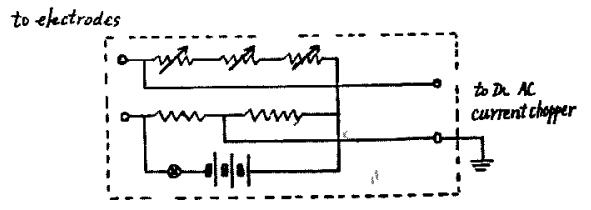

装置は第 2 図の如き装置を使用し，皮虚電流反射诽定 用電極は $20 \mathrm{~mm} \times 15 \mathrm{~mm}$ の銀板を使用し 足蹠に食監蝴 


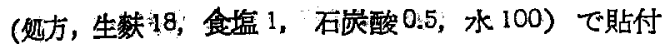

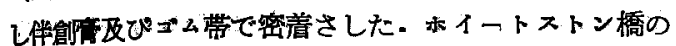
出力管600，交流飞駆動した日進電波株式会社製 LCD1006型 current chopper を通し交流電源 C-R 結合增 巾器飞増巾し，その出力を 608 交流で同期整流して入

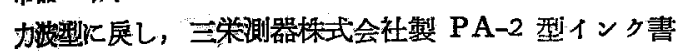
きがバハメーターをを使用した自製のオッシログラフに 入れ，検查の全释過にわたり記録観察した（第 3 区). オッシログクフの記録紙の送り装置は赫井電機製 C II 型フオノモーターを利用し毎分約 $18 \mathrm{~cm}$ の送り速度を 得た.

\section{第 3 図}
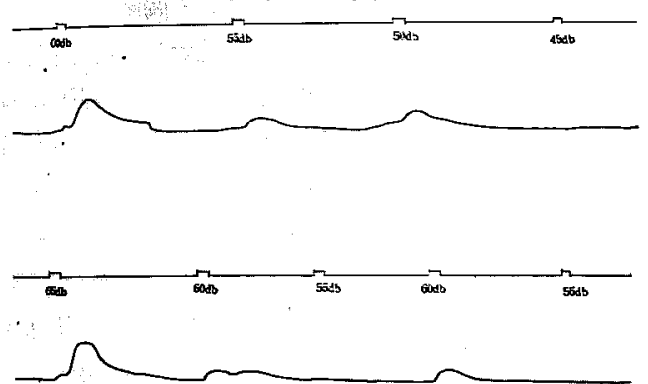

音源としては Maico 社製 MAI型オージオメーダー を使用し，附属ムービンタ゚ニイル型レシーバーによつて $500,1000,2000,4000$ の各周波数で一10db から100db迄 の任意の音を得た。なおオージオメーターのインタラプ タースイッチ汇マイタロスイッチを附加乙，信号用ペン を動加して音刺㦸をPGSR波型を同一紙面に記録した。

電気刺戱は第 4 図の装置を使用した。20 万至 $120 \mathrm{~V}$ で2乃至 $12 \mu \mathrm{f}$ の蓄電器を充電し, その放電電流を下腿 中央矂腸笳部に電極用食塩糊で貼付した $10 \mathrm{~mm} \times 10 \mathrm{~mm}$ の銀板電趣に尊いた。

第 4 図

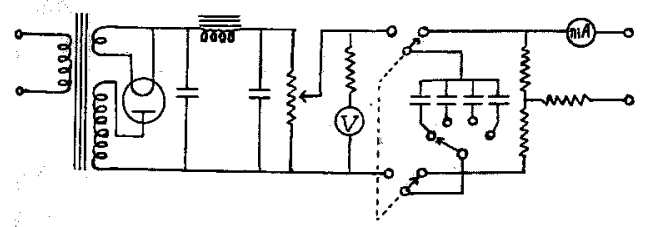

第 2 節 被 検 者

1. 西耳聴力正常者 20 名, 年令 8 才乃至 23 才平均 15 才 2 片耳正常片耳中等度難㯖のもの 18 名, 年令け 8 才 双至28 才平均 13 才

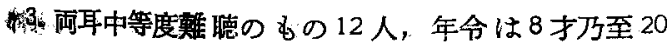

才平均 16 才

(1.2.3. は岡山大学耳奥咽潪秘入院患者)

4. 受持教師により 聴力検查が行なわれ 残聴のあつた

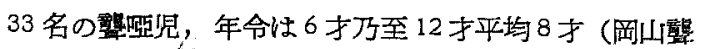
哭学校生徒)

\section{第3 節 実験方法}

被検者に充分明瞭に聞えると思われる音を条件刺战之 し，その音を 4 秒間聞かせ次いで 0.5 秒後に無条件刺战 である電気刺韩を与えた・条件刺战音は聴力ほ心゙正常と 思われるすには $500 \mathrm{cps} 30$ 万至 $40 \mathrm{db}$, 中等度難聴者 には60 乃至 $70 \mathrm{db}$ ，監血児には90 万至 $100 \mathrm{db}$ を用い た。閾値上 30 乃至 $40 \mathrm{db}$ の音を急激に与えると多くの 場合音に対する直接反射としての皮㙁電流反射の発現を みるので，それも一つの指標として条件刺战音の大きさ を定めた。

以上の如き条件刺㦸及び無条件刺㦸の組合せを約 40 秒乃至 50 秒の間隔で綠返し，条作付けを行い，音響刺 㦸のみで充分な皮腐電流反射が 得られるよらになつた ら，音響刺㦸のみでは皮虐電波反射が起らなくなる迄 $5 \mathrm{db}$ つつつ音響刺㦸を弱めて行き，皮虐電流反射を起し 得た最後の音の強さを求め，これを少なく之も2 回行い 2 回ともその成續が一致することを礁め，その音の強さ を最低可聴閵とした。 50 回以上条体付けを行い条件付 け不能のもの及び剆定值一定せず，毎回その差が $10 \mathrm{db}$ 以上あるものは一応検査不能例として処理した．更に本 㭘查終了後引続き普通の自覚的㬝力検查を同一のオージ オメーターで行つた。

\section{第3 章 実験 成 績}

第 1 節 正常耳の PGSR 法並びに自覚法による検 查成績

而耳聴力正常な平均年令 15 才の 20 人, 片耳聴力正常 の平均年令 13 才の 18 人に PGSR 法を施行し，成續の 得られたものは両耳正常者 20 人中 13 人で平均年令 13 寸の 26 耳, 片耳正常者 18 人中 10 人で平均年令 12 才の 10 耳で計 36 耳であつた (第 1 表).

PGSR 法による闒値が自党法による闒値上りも高い 時その差を(ト)，PGSR 法による閚檤が自覚法による 閶値よりも低い持その差を(一)とすれば，その差は第 2 表の如く $-15 \mathrm{db}$ から +20db にわたつて分布する。 そしてその測定誤差を $5 \mathrm{db}$ とすれば $500 \mathrm{cps}$ で 36 耳 中 18 耳 $50 \% ， 1000 \mathrm{cps}$ では36耳取 21 耳 $58 \%$ ，2000。 cpsでは36耳中 22 耳 $61 \%$ ，4000cpsでは 36 耳中 19 耳 $53 \%$ の一致をみた。更にその誤差範囲を $\pm 10 \mathrm{db}$ に拡 
第 1 表

\begin{tabular}{|c|c|c|c|c|c|c|}
\hline & \multicolumn{2}{|c|}{ 全被模者 } & \multicolumn{2}{|c|}{ 极查成功倒 } & \multicolumn{2}{|c|}{ 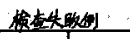 } \\
\hline & 人数 & 平均铃 & 人数 & 平法铚 & 人数 & 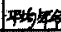 \\
\hline 而耳正敞 & 20 & 15 & 13 & 13 & 7 & 17 \\
\hline 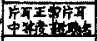 & 18 & 13 & 10 & 12 & 8 & 13 \\
\hline 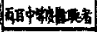 & 12 & 16 & 8 & 16 & 4 & 17 \\
\hline 小就 & 50 & 14 & 31 & 13 & 19 & 15 \\
\hline 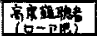 & 30 & 8 & 27 & 8 & 3 & 8 \\
\hline 合尌 & 80 & $i 2$ & 58 & 10 & 22 & 14 \\
\hline
\end{tabular}

第 2 表 正 常 耳

\begin{tabular}{|c|c|c|c|c|}
\hline 周波数 & 500 & 1000 & 2000 & $4000 \mathrm{cps}$ \\
\hline Sel & 36 & 36 & 36 & 36 \\
\hline-1506 & f & 0 & 0 & 1 \\
\hline$=10$ & -2 & 4 & & $\frac{3}{4}$ \\
\hline 0 & 3 & 7 & 6 & 4 \\
\hline \pm 5 & $z$ & 10 & II & \\
\hline+10 & 9 & 7 & 7 & 6 \\
\hline+15 & 4 & 5 & 6 & 5 \\
\hline+20 & 2 & 2 & 0 & 2 \\
\hline $\pm 5 d b$ & $50 \%$ & $58 \%$ & $61 \%$ & $53 \%$ \\
\hline
\end{tabular}

大するとし $500 \mathrm{cps}$ では36耳中 29 耳 $81 \%$ ，1000cps で は36耳中 29 耳 $81 \%$ ，2000cps では36耳中 30 耳 $83 \%$ ， $4000 \mathrm{cps}$ では36 耳中 28 耳 $78 \%$ の一致をみた。以上の .500, $1000,2000,4000$ 各周波数に指ける成續を平均する とその誤差 $\pm 5 \mathrm{db}$ では $56 \% ， \pm 10 \mathrm{db}$ では $80 \%$ が一致 するといら成續を得た。

第2節 中等度難㯖耳の PGSR 法並びに自覚法に よる検查成漬

片耳中等度難㯖者 18 人平均年令 13 才，両耳中等度難 聴者 12 人亚垃年令 16 才に PGSR 法を施行し，成續の 得られたものは，片耳中等度難聴者 10 人 10 耳で平均年 令 12 才，両耳中等度難㯖者 8 人 16 耳平均年令 16 才計 26 耳であつた (第1表).PGSR 法による闒值と自覚 法による閾値との差を正常耳の場合と同様に処理すれ ば，その誤差は第 3 表の如く $-15 \mathrm{db}$ から+20dbに わたつて分布する. そして正常耳の時と同様その誤差範 网を土5db とすれば 500:ps・で26耳中 16 耳 $62 \%$ ， $1000 \mathrm{cps}$ では 26 耳中 19 耳 $73 \%$ ，2000cps では 26 耳中

第 3 表 中等度敬聴耳-

\begin{tabular}{|c|cccc|}
\hline 周波数 & 500 & 1000 & 2000 & $4000 \mathrm{cos}$ \\
\hline 正数 & 26 & 26 & 26 & 26 \\
\hline$-15 d 6$ & 1 & 1 & 0 & 2 \\
-10 & 0 & 0 & 2 & 1 \\
\hline-5 & 3 & 3 & 2 & 1 \\
0 & 4 & 6 & 6 & 4 \\
+5 & 9 & 10 & 7 & 7 \\
\hline+10 & 4 & 2 & 5 & 4 \\
+15 & 4 & 4 & 2 & 5 \\
+20 & 1 & 0 & 2 & 2 \\
\hline $\pm 5 d 6$ & $62 \%$ & $73 \%$ & $58 \%$ & $46 \%$ \\
\hline
\end{tabular}

15 耳 58\%，4000cps，では 26 耳中 12 耳 46\%が一致し た. 更にその誤差範囲を 士10db とすれば，500cpsで は26耳中 20 耳 $77 \%$ ，1000epsでは 26 耳中 21 耳 $81 \%$ ， 2000 cps では 26 耳中 22 耳 $85 \%$ ，4000 cps では 26 耳中 17 耳 $65 \%$ が一致市るのを認めた。 そして 500, 1000, 2000,4000 各周波数に我ける 成績を平均卞ると $\pm 5 \mathrm{db}$ の誤差範囲にあるもの 60\% $\pm 10 \mathrm{db}$ の誤差範囲にある るの77\%であつた。

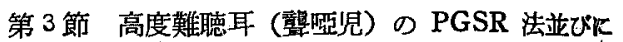
自覚法による検查成絆

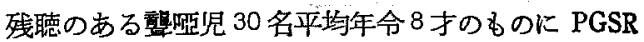
法を施行し，成續の得られたもの 27 名 54 耳平均年命 8 才であつた(第 1 表). PGSR 法による䦪値と自覚法に よる間值との差を正常耳及び中等度難㯰耳の場合と同様 に処理すれば，その誤差は第 4 表の如く -20db から +30db にわたつて分布する. そして誤差が $\pm 5 \mathrm{db}$ 以内 のものは $500 \mathrm{cps}$ では 54 耳中 33 耳 $61 \%$ ，1000 cps て は 54 耳中 32 耳 $59 \% ， 2000 \mathrm{cps}$ では 52 耳中 31 耳 $60 \%$ ， $4000 \mathrm{cps}$ では 51 耳中 31 耳 $61 \%$ であつた. 更にその䛊 差を $\pm 10 \mathrm{db}$ に㹡大すると $500 \mathrm{cps}$ では 54 耳中 44 耳 $81 \% ， 1000 \mathrm{cps}$ では 54 耳中 40 耳 $74 \%$ ，2000cps では 52 耳中 39 耳 $75 \%$ ，4000 cps では $5 \mathrm{i}$ 耳中 38 耳 75\% が 一致した．以上各周波数に和ける成績を平均すると誤差 $\pm 5 \mathrm{db}$ で 60\%士10dbでは76\%なる成績を得た。

第 4 表 高度難聴耳

\begin{tabular}{|c|cccc|}
\hline 圈波数 & 500 & 1000 & 2000 & $4000 c p s$ \\
\hline 臬迹 & 54 & 54 & 52 & 51 \\
\hline$-20 d b$ & 0 & 0 & 3 & 1 \\
-15 & 3 & 2 & 1 & 2 \\
-10 & 6 & -3 & 5 & 3 \\
\hline-5 & 8 & 13 & 4 & 4 \\
0 & 16 & 11 & 15 & 16 \\
+5 & 2 & 8 & 12 & 11 \\
\hline+10 & 5 & 5 & 3 & 4 \\
+15 & 3 & 4 & 4 & 3 \\
+20 & 3 & 5 & 1 & 3 \\
+25 & 1 & 2 & 2 & 3 \\
+30 & 0 & 1 & 2 & 1 \\
\hline $\pm 5 d b$ & $61 \%$ & $59 \%$ & $60 \%$ & $61 \%$ \\
\hline
\end{tabular}

\section{第 4 章 考按}

聴覚という感覚の複雑な機能の測定のため現在迄多く の観点より気導，骨尊検查，補充現象の測定，語音検查 等多くの方法が考按され，現在の耳科学の弾しい発展を もたらした。しかし乍らこれらの測定法は，すべて被检 者の協力に依る自覚的底答によつて行うすのである.普 通の成人に和いてはこれらの検查で協力が得られ検查る 円滑に行えるが，幼小昌であるとか，成人に执いてる神 
経精神科的矣患のあるもの，あるいは聴力詐称の場合に 括いてはその協力は得られず，すへてての自覚的応答によ る梌查は失敗汇終る事が尠くない，このため他覚的㭘查 法の必要が痛感され，多くの研究者が種くな方法を考案 した. 1948 年 Kobrak は聴小施の音響による収縮を鼓 膜穿孔より直接観察し，又㪗膜に透明化の操作を施し て，去れを観察しようとしたが充分ではなかつた．文蝸 牛電知反応，更汇第 8 神経の活動電流に関する実験が諸 家により行なるれたが，いずれる基碟的な神経学的，生 理学的実稌たるに止まり，臨床に実際に用うるに至つて いない，更に䏚波の利用も多くの研究者により試みられ つつあるが末だ完全な方法は見出されていない現状にあ 3.

皮虐電流反射は最初Féré によつて 1888 年に発見さ

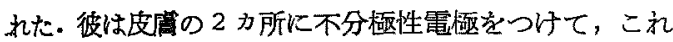
に鋭敏な電流計をつなぐと，その人の感動，與奮その他 各璉の刺战に応じて電流計が一過性の電流変化を示すの を放た。矢の後 Veraguth (1904) はその回路にあらか しめ弱い電流を通じておくと，電流变化が大きく観察に 便利であることを明らかにした。この現象は先の性質上 特酒理学者の注目を惹き，文生理学者によつても多く の研究が行なかれた結果，この現象は特に精神作用と直 接結びついた人間個有のものでなく，猿，犬，猫等にも 認められる生理現象であることが明らかにされた・最近 の研究によればこの現象は大脳皮質前運動領および視床 下部仅反射中枢を拉き，交感神経を遠心路と乙，汗腺を 反応器官とする自律神経性反射であって，その場合電流 を通しないFéré の方法では交感神経刺軲による汗腺 の活動電位を見たものであり，Veraguth の皮膚通電法 虹皮虙の電気抵抗の減少を見るもので，この電気抵抗の 减少住として腺細胞形質膜の分橾性の低下に上るもの であうらと云われている。

他敩的㯖力検查のために皮碎電流反射を利用しょらと 云5試及任 Michels 及び Randt (1947)に上つて最初 ル企てられた. 両氏はオージオォータ一や音文の音の刺 战に対する皮層電流反射を脳波描写器を用いて記録した が，条件付けの方法を用いなかつた－従つて音の刺战に 対する皮唐電流反射は音刺战を繰返している内に急速に 减弱する. 更に最初の反射そのものも闎值上相当大きな 谙でなくては現れない．即らこの方法では聞えるか聞 兑ないかの定性的検查たるに止まり，何処まで聞えるか の定量的検查即ち最低可聴閔の測定ができなかつた。

1948年 Bordley 及び Hardy 㤌皮䖉電流反射と
Pavlov の条件反射とを利用した Psycho Galvanic Skin Responce Audiometry, PGSR 法と呼灾他覚的 倹查方法を考案し興味ある成績を報告した，以後 Kirschner, Goodhill, Goldstein, Barr, Maspetiol, 森本, 志井田，島，清水等の本法に関する報告があるが，その 使用した装置，成績孔種くであり，その適応範囲，信頼 度にも種々異論があるので以下私の成績と比較検討して みる.

皮属電流反射測定回路として現在迄に使用されている 万法としては藤森化よれば単純回路, 補償式回路, 蓄電 器式回路，ホイートストン梧回路がある．単純回路は高 感度電磁タッシログシフに直接接統して写真撮影を行ら には都合が良いが，增巾してペン書き式記録装置に入れ るには不便である.蓄電器式回路は基線が一定し指針の ずれがないが，時定数を相当大きくとつても，現象の周 期が非常に長いのでぞらしても波型の雪，变型を生じ， たが単に皮盧電流反射の存在は知り得ても精密な測定が できない：ホイートストン橋回路及び補償式回路は久点 として皮鹰の分極作用化上る皮虔抵抗の経時的变化に上 る基線のずれがあるが，波型描写が正磪なので Bordley \& Hardy 並びにこれに倣つた諸家の多数はホイートス トン橋回路定使用し，その出力交流電源の直結直流增 巾器で増巾しペン書きオッシログラフに入れ記録観察し た・これに反し皮膚電流反射の有無を見るのに検流計の ふふれ又はマジックアイの開閉を読んで測定する方洗をと つた研究者，島，清水があるが，実際に皮厤電流反射の

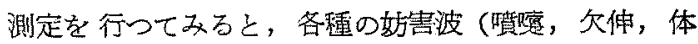
動，外界の種やの妨害刺㦸等による）との鑑別には波型 の描写が便利であつたので，本実験にはホイートストン 橋回路を使用し検查の全経過沉放たり記氽観察した。又 森本, 志井田も検流計のみに頼らず種々の記録装置を併 用することが望ましいと述べている。

Maspetiol は直流電橋の代りに交流電橋を使用した。 彼が交流電橋の利点として挙げているのは交流使用によ り分極作用の現れなくなる点，及び增巾に便利な点を 挙げているが，直流電橋の分極作用による基点のずれは 電橋の調整により規制し得られる・文交流電橋では抵抗 と容量の両方を調整せ齐ばならず，波型が基線の片側へ のみ折り返された型で現れる欠点があるので私は直流 電橋使用し，增巾の点は後述する如くホイートストン 橋の直流変化を交流に変えて增巾し，次いでとれを同期 整流してもとの波型に厣す方法をとり，安定に充分な增 巾を行らことができた。 
水イートストン橋出力の增巾に使用される增巾器は皮 膚電流反射が 全経過数秒乃至数 10 秒切わたる直流変化 であるため，脳波あるいは筋電図用の如き通常の C-R 結合の真空管增巾器は使用できない. Bordley \& Hardy の使用した Richter の装置は全交流電源直結直流增 巾器で装置は複雑高価であり，かつ不安定となる恐れる あるので私は前述の如く6.3V 60 cpsの交流で駆動した日 進電波 K.K 製 LCD 100 型 DC-AC current chopper で入力そ交流変化に直し C-R 結合增巾器で增巾し必要 にして充分な安定度と增巾度を得た。そしてこの增巾器 出力を同期整流し入力波型に戻し三栄測熙製作所製の $2 \mathrm{~mA}$ ペン書き電流計に入れ所要の波型を得た。

皮阅電流反射測定用電極亡しては $20 \mathrm{~mm} \times 15 \mathrm{~mm}$ の 銀板電極を 2 枚使用した・いずれる電極用食塭糊で足䟕 に装用した，皮膚電流反射が汗腺活動によるものである 以上電極は当然汗腺の多い部位に装置されるべきであ

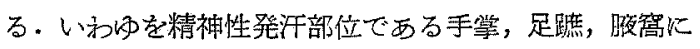
おいて特に反射が現れ易いことは古くから知られてい るが，現在迄の研究者の多〈は手掌及び手の背部，ある いは足踓及び足背に電極を置いた。これらは2つの電極 の短絡を防ぐためとも考えられるが，皮盧電流反射を明 膫に検出するためには 2 つ電極を2つとも汗腺に富ん だ部位に置くことは当然であるら．又藤森によ礼ば手堂 手背の如く異なる部位の皮膚電流反射は潜伏時間のみな らず，時に著しい波型の相違が見られるといら。この場 合 2 つ波型が合成され復椎な波型上なる恐れがある。 この点からも2つの電極を近接した部位に付けることが 望をしい。2つの䉓極間の短絡は1個宛伴創塾で周囲を 張ることにより完全に防ぎ得た。手掌あるいは手指に電 極を付けなからたのは足が手に比較して被检者の意識的 乃至無意識的運動がはるかに少なく固定が容易であり， そのため電㥛の接触王の恋化による防害波の出現も少 く，又電極装着に上る被検者の不快感も手に比較し多少 とる少いと思われたからである。

電気湖战装置としては第4 図の如き回路による蓄電器 放電電流刺战装置を算作使用した。図の如く双極双投ス イッチを使用し放電時には蓄電器を充電回路と全く切り 離乙回路の絶縁不良に上る危険を防止した。電気刺㦸と してはBordley \& Hardy, Goldstein, 島, 森本,志汼田 等の使用した感応ニイルによる感応電流刺战之 Goodhill, 清水の使用した 蓄電器の放電電流による 直流電流 刺战の 2 種類に大別できる. Goodhill の行つた檑々の 波型の電気刺㦸に上る不快感乃至疼痛と皮属電流反射々
の関俰の研究に上れば，蓄電器放電電流が皮庙電流反射 の大きさ比し不快感竽疼痛感が最も少く小児も良く 耐吝たと云らので本実験に和いては上記の装置を製作位 用した。

PGSR 法の失敗原因は多々あるが第1 《皮膚電流反 射の非常に出難、場合がある.皮虞抵抗が高いと皮虎抵 抗の低い場合に比して同一の增门度で波型の振巾が非常 に小さくしか現わず，測定に困難を感ずる場合があっ た・この場合は反射型電気ストーブによつて電極装着部 位を温めたり，電気刺战のみを数回続けて与古ることに 上り，皮瀮電流反射の測定が容易に行な光る点まで，皮 有抵抵抗を低下させ得る場合が多く, Barr, Bordley \& Hardy，Maspetiol 等も同様の意見を述べている. 更飞. かつる操作を行らにかっわらず皮膚抵抗高く皮獻電流反 射の出難い場合がある．これは成人では検查中に婮り をしている場合に見られるが，若年者では時ふ居眠りを していないにか入わらずか〉ることがある。この場合電 気刺韩は相当な強度を有しているにもか入わらず，何等

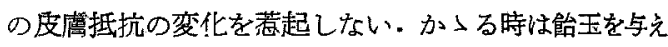
るとか，興味をそつるような絵本を見せるとかすると，

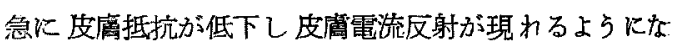
ることがあつた。

第 2 の失敗原因として条件付けの不能なる場合があ る.本実験は臨床検查を目標として行つたので，その害 験所要時間もある程度の制限を受けた・条件刺战である 検查音々無条件刺戟である電気刺㦸との組合せを綝返す 間隔は，皮膚電流反射の性質上 40 秒乃至 50 秒以上望 ましい.今 40 秒乃至 50 秒の間隔で 50 回の条件付けを 行うと大本 40 分前後の時間を要する。一方被挨者があ る程度緊張して音に反応してくれる時間付大体 1 時間以 内であろう.よつて 500，1000，2000，4000cps の 4 音を 左右闭耳について测るに要すする时間を考虑に入れると策: 件付けに許される時間は 40 分 50 回位を限度とすると思 われるので，采件付け50 回をるつて臨床検查としての 本法に許される最大回数として条件付讨を行い，50回： の条件付けでな和条件付けのできないるのは本実験で. 条件付け不能による検查失敗例とした. 50 回迄の条件 付けで条件付けに成功したものは両耳正常者 20.名中 13. 名 $65 \%$ ，片耳正常片耳中等度難聴者 18 名中 10 名 $55 \%$,

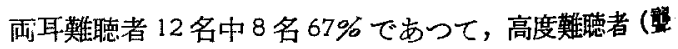
旺児）では 30 例中 27 例 $90 \%$ であつた。高度難德者に 括ける検查成功率は前 3 群と非常にかけはなれている

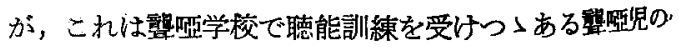


音に対する注意が正常者並びに中等度難聴者よりも高度 なためと考古られる。更に前 3 群の検查成功例と失敗例 との年令を第 1 表们ついて見ると，その年令は各ふ平均 13 才及び平均 15 才で成功例の方がや小小い，又高度 蜼㯖者の平均年令は 8 才であり，年令の差による条件っ けの奞易むあると考光られる。河田・江崎等の絉音並び 飞電気刺战による条件形成実験を見ると，青年者 7 名で 虾反射形成の開始は平均 83 回で 50 回以下で始まつたも のは7 名中 3 名 $43 \%$ であり，学令児 6 名の平㮄は 14 回 で全部50回以下で始まつている。この成續からる中は り年令による条件付けの難易むあると考无られる. 更に Straus 4 年令 21 才万至 28 才平均 23 才の正常成人 24 人に同様の実験を行い，条件付けに必要とした時間は1 分 30 秒から 1 時間 10 分で 3 人は 1 時間 45 分 150 回で 条件付け不能であつたと述べている．詳しい記蹱がない ので判然としないがこれも大体同様の成櫝ではなかつた かと思われる. 更に Goldstein \& Ludwig は18名の

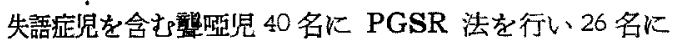

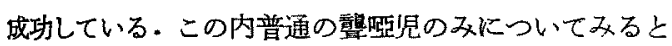
22 名中 20 名㳊成功している。これは失語症垐が特儿条 件付けにくいことを示するのであるが，それと反対に鄣 吅罟はある程度条件付けられやすいことをる示すのでは 祅ららかとも考えられる．以上の如く本実験の条件付 けの不能例においては更に条件付けの回数を增すことに 上つて成功例が增加すると考光られるが，前述の如く臨 床検查としての本実験においては条件付けの回数を增す ことは時間的制約もあり伸々困硬なので更に短時間で条 件付けの完全にできる方法が望まれる。

PGSR 法々自喾法とによる測定聴力の差は前述の如 く，正常耳 36 耳に和いてけ $5 \mathrm{db}$ 以内のものけ $500 \mathrm{cps}$ で18耳 $50 \%$ ，1000cps では 21 耳 $58 \%$ ，2000cps で 22 耳 $61 \%, 4000 \mathrm{cps}$ では 19 耳 $53 \%$ となり，中等度難聴耳 26 耳では $500 \mathrm{cps}$ で 18 耳 $62 \% ， 1000 \mathrm{cps}$ では 19 耳 73 $\%$ ，2000 cps では 15 耳 $58 \% ， 4000 \mathrm{cps}$ では 12 耳 $46 \%$ であつた。これを Hardy \& Bordley の成人20名の難 婹耳 30 耳における成續即ち両方法の差 $5 \mathrm{db}$ 以内のもの 500 cps $73 \%$, 1000cps $70 \%$, 2000cps 60\%, 4000 cps 62 \%と比較すると $500 \mathrm{cps}$ に执いてては Bordley \& Hardy の成䒈が 11 万至 23\% 合致率か゚良く，1000cps では正常 耳が約 12\% 悪く他は同様であり，2000cps では3 者は 法同粎の成結を示し，4000eps では正常者が7\% 中等度 難聴者が約 14\% 文 Bordley \& Hardy の成績に比して 悪い. 更に高度難聴者 27 名 54 耳平均年令 8 才のbのに
おけける両方法の善が $5 \mathrm{db}$ 以内のものは，前述の如く $500 \mathrm{cps}$ では 44 耳 $61 \% ， 1000 \mathrm{cps}$ では32耳 $59 \% ， 2000$ cps では 52 耳中 31 耳 $60 \%$ ，4000 cps では 51 耳中 31 耳 $61 \%$ であり，これを Bordley \& Hardy の平均年令 8 才 59 難珤耳の成續即ち両方法の差 $5 \mathrm{db}$ 以内の子の $500 \mathrm{cps} 67 \%$, 1000 cps 61\%, 2000 zps 73\%, 4000 cps 43 \% と比較するとこれる大差なく $500 ， 1000,2000$ の各周 波数で後者が合致率や小高く4000cps ではや〉低くな つている.更に第2，3，4表について耳数の最多多い段 階を求めると，第 2 表正常耳では $500 \mathrm{cps}$ \& $+10 \mathrm{db}$ ， 残る $1000,2000,4000$ の各周波数では $5 \mathrm{db}$ が最も多く， 第3 表の中等度難聴耳についてみると 500,1000 ，2000， 4000 各周波数共 $+5 \mathrm{db}$ であつた。これに反し第 4 表高 度難㯖耳では $500 \mathrm{cps}$ は Odb, $1000 \mathrm{cps}$ は $-5 \mathrm{db}$, 2000, 4000cps 共に 0db と夜る。こ和らの值から正常 者並びに中等度難聴者においては PGSR 法の方が自覚 法に比し闒值が大体 $5 \mathrm{db}$ 高く現れ，高度難聴者では 大体一致する傾向にあるが，その分布籁围怔正常者並び に中等度難聴者に比して高度難聴者のちが広いことが認 められた。

以上の如く PGSR 法は現在の所, 少くとも本実験の 年令のものに打いては，その測定可能率並びにその測定 捠差加ら見て，他党的聴力検查法乙乙て充分实用飞供乙 得る方法であると考兄らる。.

\section{第 5 章 結 語}

1. 皮虚電流反射湘定回路としてはホ1ートストン橋 回路を使用し入力をカレントチョッパーによるDC-AC コンバーターを通し普通の時定数を持つ C-R 結合增巾 器で增币しその出力を同期整流してペン亩きオッシログ ラフに入れる皮膚電流反射記録装置を試作し，皮虞電流 反射の記録に必要にして充分な安定な增巾度が得られ た。

2.この装置を使用し, 各種聴力者に $500,1000,2000$, $4000 \mathrm{cps}$ の各周波数に和いて PGSR 法を行い検查の全 㳗過にわたり記録観察し，次いて自賞法を行い両方法の 成績を比較検討した。袖方法に上る成績の羑 $\pm 5 \mathrm{db}$ 以 内のものは周波数により 46 万至 $73 \%$ であり，士10db 以内のるのは 65 乃至 $85 \%$ であり他党的聴力検查法とし て充分実用に供し得る信頼度を有する。

3. 50 回以下の条件付けで条件付けられたものは両耳 正常者 20 人中 13 人 $65 \%$ ，片耳正常片耳中等度 難聴者 18 人中 10 人 $55 \%$ ，両耳中等度難㯖者 12 人中 8 人 $67 \%$ ，

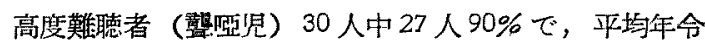


14 才（検查成功例平均 13 才，検查失敗例平均 15 才）の 前 3 群化比し，平均年令 8 才（検查成功例，失敗例共に

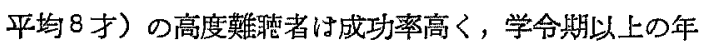
令ては年少のもの程条件付けられやすい傾向にあること が認められた。

4. 高度難衈者（算啞罗）においては他の被検者群と異 なり音に対する注意をひきやすく，条件付けが行い易い
ことが茨められた。

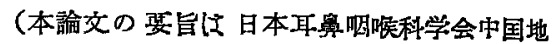
方会篗 74 回例会, 同 77 回例会, 第 2 回オー; オロギー学会にまいて発表した).

（原稿到茞 $=$ 㗁和 34529 日） 